\title{
Cytotoxic Activity of Methoxy-4'amino Chalcone Derivatives Against Leukemia Cell Lines
}

\author{
Arina Novilla ${ }^{1}$, Mustofa $^{2}$, Indwiani Astuti ${ }^{2}$, Jumina $^{3}$, Hery Suwito ${ }^{4}$ \\ ${ }^{1}$ Doctoral Program, Faculty of Medicine, Gadjah Mada University, Yogyakarta, Indonesia \\ ${ }^{2}$ Faculty of Medicine, Gadjah Mada University, Yogyakarta, Indonesia \\ ${ }^{3}$ Faculty of Chemistry, Gadjah Mada University, Yogyakarta, Indonesia \\ ${ }^{4}$ Doctoral Program, Faculty of Chemistry, Gadjah Mada University, Yogyakarta, Indonesia
}

Background: Chemotherapy is a common treatment for leukemia as well as in other cancer treatment. The lack of tumor selectivity and development of multi-drug resistance by chemotherapy caused the development of new strategy in cancer treatment become a pressing need. This study was performed to evaluate the anticancer activity and selectivity of seven derivatives of chalcones against K562 and HL-60 leukemia cell lines.

Materials and Methods: The cytotoxicity of chalcone's seven derivatives (compound 1-7) was tested by using 3-(4,5-dimethylthiazol-2-yl)-5-(3-carboxyme-thoxyphenyl)-2-(4-sulfophenyl)-2H-tetrazolium (MTS) method. The percentage of cell mortality data was calculated then the $\mathrm{IC}_{50}$ was analyzed using probit analysis (SPSS 17). The selectivity index (SI) then calculated from IC $\mathrm{I}_{50}$ ratio of normal lymphocyte cells and cancerous cells line (HL-60 and K562).

Results: The $\mathrm{IC}_{50}$ of almost all seven tested compounds were lower in $\mathrm{HL}-60$ cell lines (ranged from 1.57 to $9.63 \mu \mathrm{g} / \mathrm{mL}$ ) than K562 cell lines (ranged from 5.87 to $52.56 \mu \mathrm{g} / \mathrm{mL}$ ), except for Compound $7(5.87 \pm 0.15 \mu \mathrm{g} / \mathrm{mL}$ ). The number and position of methoxy groups in chalcone derivatives influenced the anticancer and cancer selectivity of chalcone derivatives.

Conclusion: The results revealed that the number and position of methoxy groups in chalcone derivatives influenced the anticancer and cancer selectivity of chalcone derivatives.

Keywords: anticancer, chalcone derivatives, methoxy-4'-amino chalcone, leukemia, cytotoxic, selectivity

\section{Introduction}

Leukemia is cancer of the white blood cells characterized by widespread, rapid, and disorderly proliferation of leukocytes and their precursor as well as by the presence of immature leukocytes in blood often in very large number. ${ }^{1,2}$ Although leukemia is a rare disease, however it exceeds a cause of death from many of the acute communicable diseases due to its fatal character. ${ }^{2}$ In 2012, leukemia suffered by approximately 352,000 people around the world and caused 265,000 death. $^{3}$

Chemotherapy is common for the treatment of leukemia as well as other cancer. ${ }^{4}$ Nowaday, chemotherapy is one of the most effective and potent strategies to treat

Date of submission: October 31, 2018

Last Revised: December 5, 2018

Accepted for publication: December 6, 2018

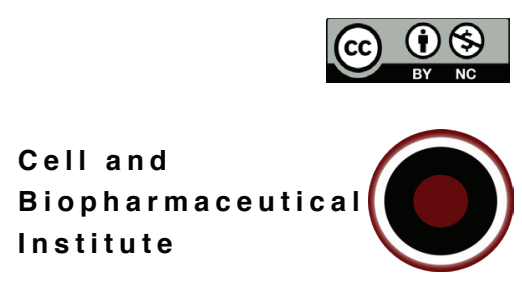

Corresponding Author:

Arina Novilla

Doctoral Program, Faculty of Medicine

Gadjah Mada University

Jl. Farmako, Sekip Utara, Yogyakarta, Indonesia

E-mail: arin_novilla@yahoo.co.id 
cancer. However, the use of anticancers in the chemotherapy is limited. All the anticancer currently available have severe side effects on normal cells due to their nonspecifity. In addition, the resistance of cancer cells to the anticancer remains a significant impediment to successful chemotherapy. ${ }^{5}$ Therefore, the need to discover and develop new anticancers with specific target and novel mechanisms is urgent.

Natural products are important and valuable resources for anticancer discovery and development. Natural products demonstrate important structural diversity and offer a wide variety of novel compounds with novel anticancer mechanims. ${ }^{6,7}$ Vincristine, irinotecan, paclitaxel, actinomycin $\mathrm{D}$, mitomycin $\mathrm{C}$, and doxorubicin are classic examples of natural-derived anticancer that used in clinic. During the last few years, natural-product-based drug discovery is increasing based on new technologies, such as combinatorial synthesis and high-throughput screening, and their associated approaches. ${ }^{6}$

Chalcones are precusor of flavonoids that widely distributed in plants and one of potential natural compounds to develop as anticancer. A number of chalcones have been isolated or synthesized and evaluated for their cytotoxicity on cancer cell lines culture and their anticancer activity on cancer animal model. ${ }^{8,9}$ Furthermore, the molecular mechanisms of anticancer action of chalcones have also investigated. The chalcones exhibited anticancer activity through multiple mechanisms included cell cycle disruption, angiogenesis inhibition, tubulin polymerization inhibition, apoptosis induction and blockade of nuclear factor-kappa B (NF-kB) signaling pathway. ${ }^{9-13}$

In our previous study, some derivatives of methoxy amino chalcone have been synthesized and evalauated for their cytotoxicity on breast cancer cell culture. ${ }^{14,15}$ In this study we evaluated the cytotoxicity of the methoxy amino chalcone derivatives on (human acute promyelocytic leukemia (HL-60) and human chronic myelogenous leukemia (K562) cells line. The cytotoxicity of these derivatives on normal lymphocyte cells was also evaluated in order to determine thier selectivity index (SI).

\section{Materials and methods}

\section{Tested Compounds}

The methoxy amino chalcone derivatives were synthesized by Drs. Hery Suwito in the Department of Chemistry, Faculty of Science and Technology, Airlangga University,
Surabaya, Indonesia. The chemical structure of the methoxy amino chalcone derivatives are showed in Table 1.

\section{Cell Culture}

The HL-60 cell line, K562 cell line and limphocytes were used for cytotoxic screening of the tested compounds. The HL-60 and K562 cell lines were obtained from Stem Cells and Cancer Institute (SCI) Jakarta, Indonesia. The cell lines were maintained in Iscove's Modified Dulbecco's (IMD) medium supplemented by $10 \%$ fetal bovine serum (FBS), and 2\% penicilin-streptomycin. The cell lines were maintained at $37^{\circ} \mathrm{C}$ in a $5 \% \mathrm{CO}_{2}$ atmosphere with $95 \%$ humidity. Lymphocytes were isolated from whole blood using Histopaque (Sigma) according to the manufacturer's instructions. The lymphocytes culture were then maintained in RPMI1640 medium supplemented with 1\% non-essential amino acids, $1 \%$ L-glutamine, $100 \mathrm{U} / \mathrm{mL}$ penicillin, $10 \mathrm{mg} /$ $\mathrm{mL}$ streptomycin and $10 \%$ heat inactivated fetal calf serum at $37^{\circ} \mathrm{C}$ in in a $5 \% \mathrm{CO}_{2}$ atmosphere with $95 \%$ humidity.

\section{Cytotoxic Assay}

Cytotoxic activity of the tested compounds on the treated cells were determined using the 3-(4,5-dimethylthiazol-2yl)-5-(3-carboxyme-thoxyphenyl)-2-(4-sulfophenyl)-2Htetrazolium (MTS) colorimetric assay developed by Yoon, et al., ${ }^{16}$ and Khan, et al., ${ }^{17}$ after modification. Around $90 \mu \mathrm{L}$ of the treated cells culture at density of $10^{4}$ cells/well were distributed in 96-wells plates. Ten microlitres of the tested compounds at various concentration $(0.2-100 \mu \mathrm{g} / \mathrm{mL})$ then added to each well, except for the negative control the well was added with the culture medium and for the positive control the well was added with imatinib or accutane. The plate then incubated for $24 \mathrm{~h}$ at $37^{\circ} \mathrm{C}$ in a $5 \% \mathrm{CO}_{2}$. Following the incubation, the mixture further added with 20 $\mu \mathrm{L}$ of MTS, incubated for $4 \mathrm{~h}$ at $37^{\circ} \mathrm{C}$ in $5 \%$ of $\mathrm{CO}_{2}$. The absorbance then measured at $\lambda$ of $490 \mathrm{~nm}$ using a microplate reader. ${ }^{18}$ The cell growth inhibition was determined with the equation:

$$
\% \text { of cell growth inhibition }=\frac{\text { OD of control cell }- \text { OD of treated cell }}{\text { OD of control cell } \times 100 \%}
$$

For this MTS method, $\mathrm{IC}_{50}$ (concentration that inhibit 50\% cell growth) values were determined using probit analysis. The $\mathrm{IC}_{50}$ values was obtained from three independent experiments. Furthermore, selectivity index (SI) was determined from the $\mathrm{IC}_{50}$ ratio of lymphocytes normal 
Table 1. Chemical structure of different methoxy amino chalcone derivatives.

\begin{tabular}{clcccc}
\hline & & & \\
\hline
\end{tabular}

and cancerous cells (K562 and HL-60). The SI value demonstrates selectivity of the tested compound to the cell lines tested. Samples with SI value greater than 2 were considered to have good selectivity. ${ }^{19}$

\section{Statistical Analysis}

Data of the $\mathrm{IC}_{50}$ values and SI were presented as mean \pm standard deviation (SD) and were analyzed using Tukey's HSD Post Hoc. A p-value less than 0.05 was considered as statistically significant.

\section{Results}

Growth inhibition of K562, HL-60 cells and lymphocytes after incubation with the tested compounds in various concentrations are presented in Figure 1. The growth inhibition in a dose-dependent manner was observed in all the treated cells by all the tested compounds. At concentration of $100 \mu \mathrm{g} / \mathrm{mL}$, all the tested compounds exhibited more than $70 \%$ growth inhibition against the K562 and HL-60 cell lines. Growth inhibition of the lymphocytes after incubation with the tested compounds at the same concentration were lower than that of the HL-60 cells. It was indicated that the tested compounds more sensitive to the HL-60 cells. The effect of tested compounds toward the K562, HL-60, and lymphocytes cells can be seen in Figure 2, 3 and 4, respectively. It can be seen that mainly the treated cells have lower density than the normal cells.

The cytotoxic activity of the tested compounds against the leukemia cell lines and lymphocytes are presented in Table 2. All seven tested compounds showed moderate cytotoxic activity with $\mathrm{IC}_{50}$ values ranged from 5.87 to 52.56 $\mu \mathrm{g} / \mathrm{mL}$ against K562 cell line and from 1.57 to $9.63 \mu \mathrm{g} / \mathrm{mL}$ against HL-60 cell line. Among all seven tested compounds, compound 7 showed the most cytotoxic against K562 cell line with the $\mathrm{IC}_{50}$ value of $5.87 \pm 0.15 \mu \mathrm{g} / \mathrm{mL}$, whereas the compound 4 showed the most cytotoxic against HL- 60 cell line with the $\mathrm{IC}_{50}$ value of $1.57 \pm 0.40 \mu \mathrm{g} / \mathrm{mL}$.

The SI of the tested compounds are presented in Table 2. Almost all tested compounds showed low selectivity with SI values ranged from 0.05 to 0.96 toward K562 cell line and from 0.45 to 5.26 toward HL-60 cell line. 
A

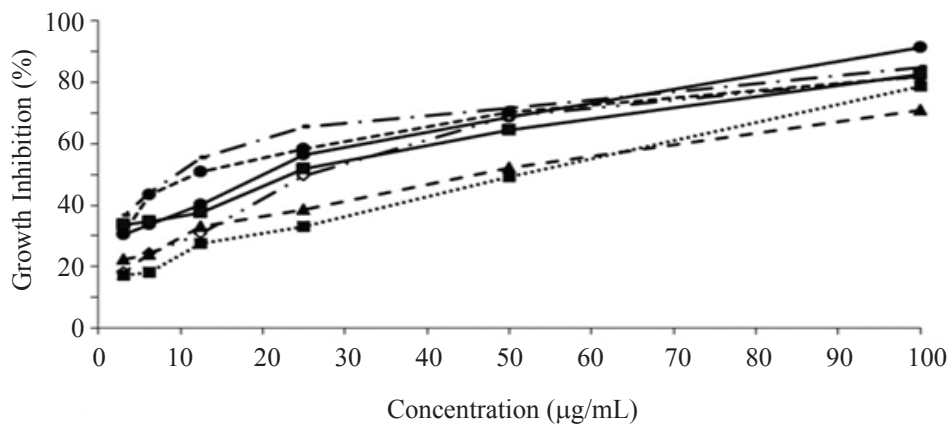

B

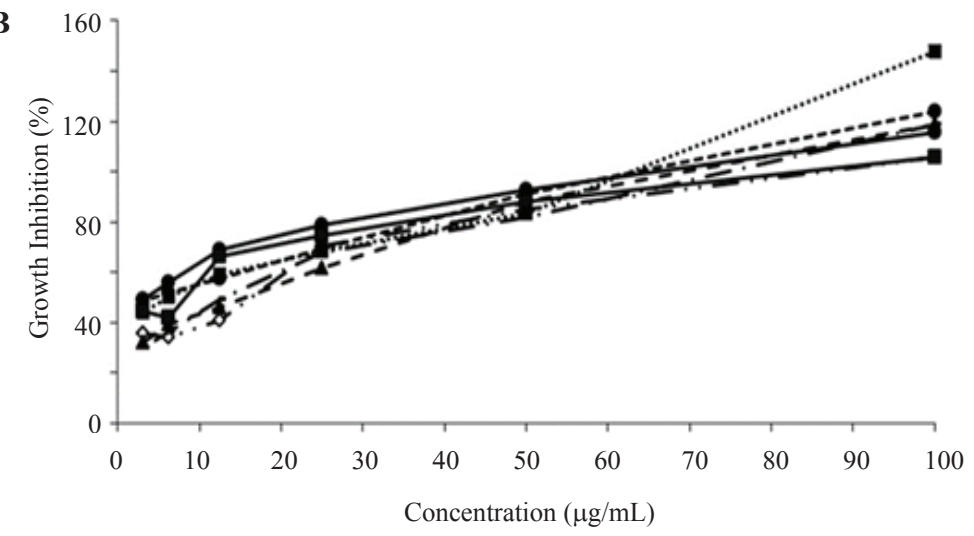

C

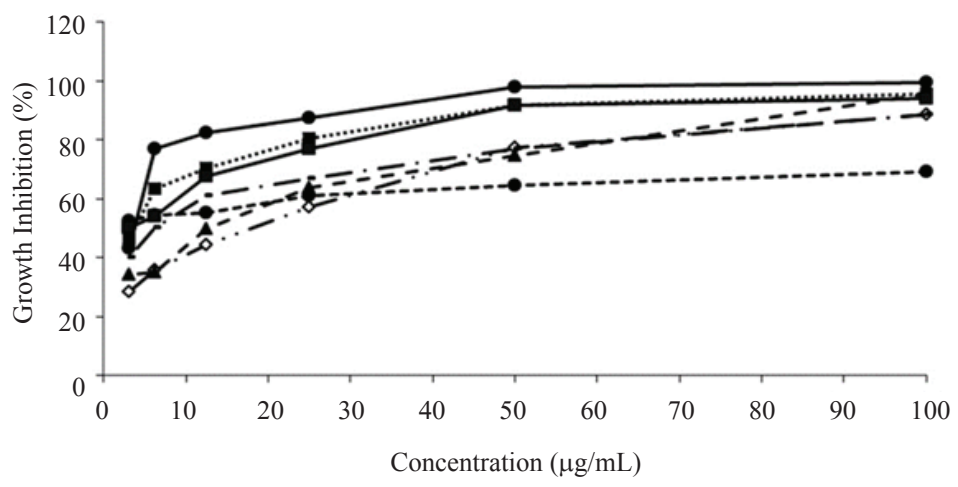

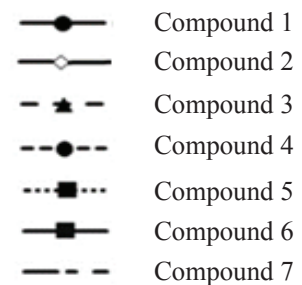

Figure 1. Growth inhibition after incubation with the tested compounds. Growth inhibition of K562 cells (A), HL60 cells $(\mathrm{B})$ and lymphocytes (C) after incubation with the tested compounds for $24 \mathrm{~h}$.
In comparison, the positive control imatinib showed high selectivity ( $\mathrm{SI}>2$ ) toward both HL-60 and K562 cell line, however accutane showed low selectivity toward K562 cell line. Among all seven tested compounds, the compound 4 showed the highest selectivity toward HL-60 and K562 cell line with SI value of 5.26 and 0.96 respectively, higher than those of imatinib and accutane toward the HL- 60 but still lower than imatinib toward the K562 cell line. The compound 5 showed the lowest selectivity toward K562 cell line with SI value of 0.05 , whereas the compound 7 showed the lowest selectivity toward HL-60 with SI value of 0.45 .

\section{Discussion}

The therapeutic activity of most anticancer drugs in clinical use is limited by their general toxicity to proliferating cells, including some normal cells. Researcher continue to develop novel cytotoxic agent with unique mechanisms of action, but many of that compounds still lack of tumor selectivity and have not been therapeutically useful. ${ }^{20}$ Some chalcone derivatives have been synthesized and evaluated for their cytotoxic activity. Various chalcones can inhibit different steps of carcinogenesis from the very early stages, including tumor initiation trough promotion, progression, 
Table 2. Cytotoxic activity of the tested compounds against the leukemia cell lines (K562 and Hl-60) and lymphocytes and their selectivity index.

\begin{tabular}{ccccccc}
\hline \multirow{2}{*}{$\begin{array}{c}\text { Compound } \\
\text { number }\end{array}$} & \multicolumn{3}{c}{ IC $_{\mathbf{5 0}} \pm \mathbf{S D}(\boldsymbol{\mu g} / \mathbf{m L})$} & & \multicolumn{2}{c}{ Selectivity Index (SI) } \\
\cline { 2 - 3 } \cline { 6 - 7 } & $\mathbf{K 5 6 2}$ & HL-60 & Lymphocytes & & K562 & HL-60 \\
\hline $\mathbf{1}$ & $10.83 \pm 0.67^{\mathrm{b}}$ & $1.76 \pm 0.20^{\mathrm{a}}$ & $2.92 \pm 1.15^{\mathrm{a}}$ & & 0.27 & 1.66 \\
$\mathbf{2}$ & $21.46 \pm 0.30^{\mathrm{c}}$ & $7.81 \pm 1.21^{\mathrm{b}}$ & $10.78 \pm 2.09^{\mathrm{ab}}$ & & 0.5 & 1.38 \\
$\mathbf{3}$ & $48.45 \pm 5.37^{\mathrm{e}}$ & $6.92 \pm 1.18^{\mathrm{b}}$ & $9.13 \pm 4.12^{\mathrm{ab}}$ & & 0.19 & 1.32 \\
$\mathbf{4}$ & $8.65 \pm 0.93^{\mathrm{ab}}$ & $1.57 \pm 0.40^{\mathrm{a}}$ & $8.26 \pm 2.29^{\mathrm{ab}}$ & & 0.96 & 5.26 \\
$\mathbf{5}$ & $52.56 \pm 1.79^{\mathrm{e}}$ & $2.49 \pm 0.84^{\mathrm{a}}$ & $2.46 \pm 0.96^{\mathrm{a}}$ & & 0.05 & 0.99 \\
$\mathbf{6}$ & $11.84 \pm 1.11^{\mathrm{b}}$ & $1.84 \pm 0.41^{\mathrm{a}}$ & $3.51 \pm 0.37^{\mathrm{ab}}$ & & 0.3 & 1.91 \\
$\mathbf{7}$ & $5.87 \pm 0.15^{\mathrm{ab}}$ & $9.63 \pm 2.32^{\mathrm{b}}$ & $4.33 \pm 0.97^{\mathrm{ab}}$ & & 0.74 & 0.45 \\
Imatinib & $2.67 \pm 0.53^{\mathrm{a}}$ & $16.59 \pm 0.77^{\mathrm{c}}$ & $42.30 \pm 17.11^{\mathrm{c}}$ & & 15.85 & 2.55 \\
Accutane & $39.47 \pm 3.14^{\mathrm{d}}$ & $7.82 \pm 0.92^{\mathrm{b}}$ & $20.44 \pm 3.72^{\mathrm{b}}$ & & 0.52 & 2.61 \\
\hline
\end{tabular}

angiogenesis, and invasion, to the very large states leading to metastasis. Synthesis or chemical modification of chalcones allows rapid generation of large number of novel compounds for anti-cancer. ${ }^{21}$ Chalcones contain a common 1,3-diphenyl, propenone template that can be modified through addition of functional groups such as aryls, halogens, hydroxyls, carboxylic groups, benzena,etc to alter the biological potential. The chemical structure of chalcone appears to play critical role in determining their molecular targets. ${ }^{22}$ In this study, seven chalcone derivatives compounds cytotoxic activity and selectivity was tested against K562 and HL-60 cells line, then compared with the activity of cancer drugs imatinib and accutane.

The seven derivatives compounds of chalcones exerted cytotoxic activity against K562 and HL-60 cell lines in concentration-dependent manner. Compound 4 and 7 showed highest cytotoxicity against K562 cell lines, comparable with those of imatinib $(p>0.05)$ and better than accutane $(p<0.05)$. Compound 4 also showed highest cytotoxicity against HL-60 cell lines, followed by Compound 1 and 6 with activity were higher than both imatinib and accutane $(p<0.05)$. This study was in accordance with Suwito, et al., study results that Compound
Normal Cells

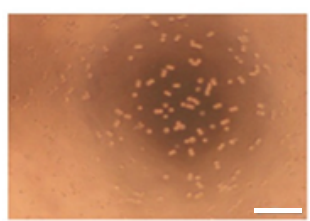

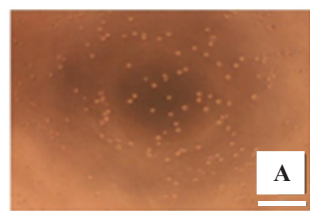

Treated Cells
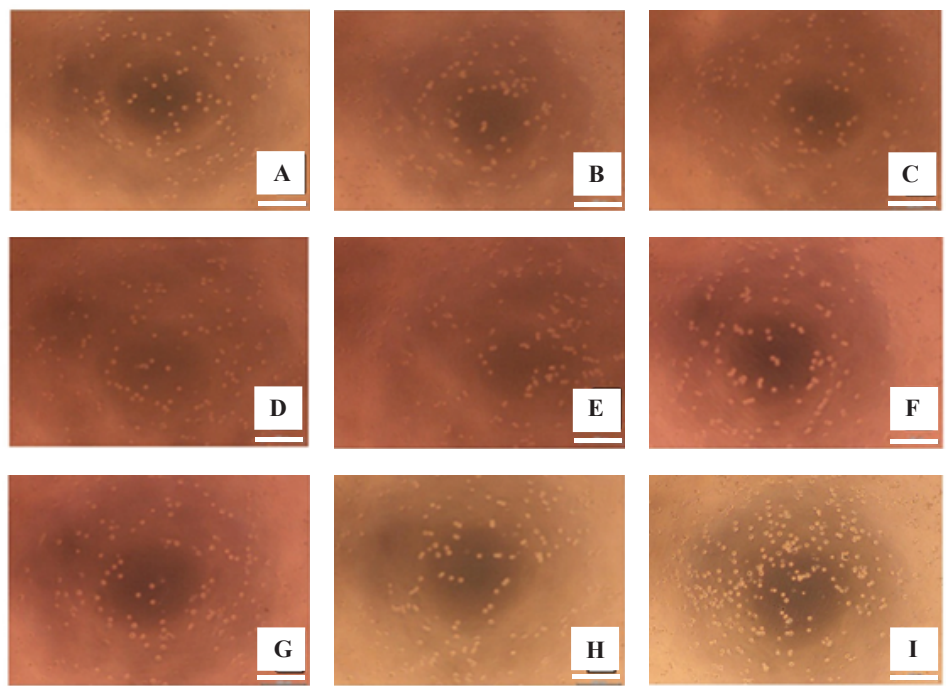

Figure 2. Morphological appearance of $\mathrm{K562}$ cells with no treatment (normal cells) and cells with treatment at concentration 100 $\boldsymbol{\mu g} / \mathbf{m L}$. Treatment cells are compound 1 (A), compound 2 (B), compound 3 (C), compound 4 (D), compound 5 (E), compound 6 (F), compound $7(\mathrm{G})$, imatinib $(\mathrm{H})$ and accutan $(\mathrm{I})$. The normal cells relatively has higher density than treated cells. White scale bar: $200 \mu \mathrm{M}$. 
Normal Cells

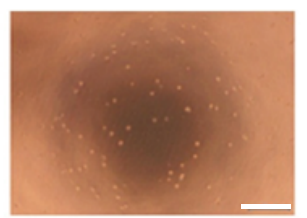

Treated Cells
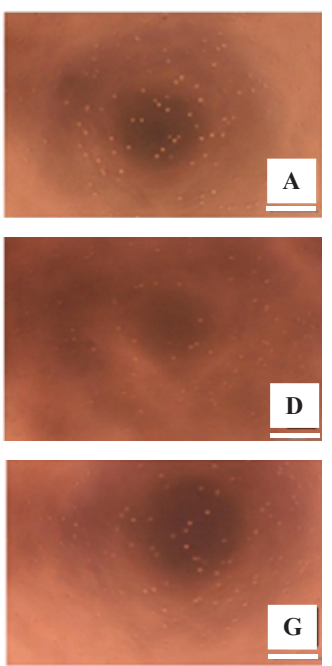
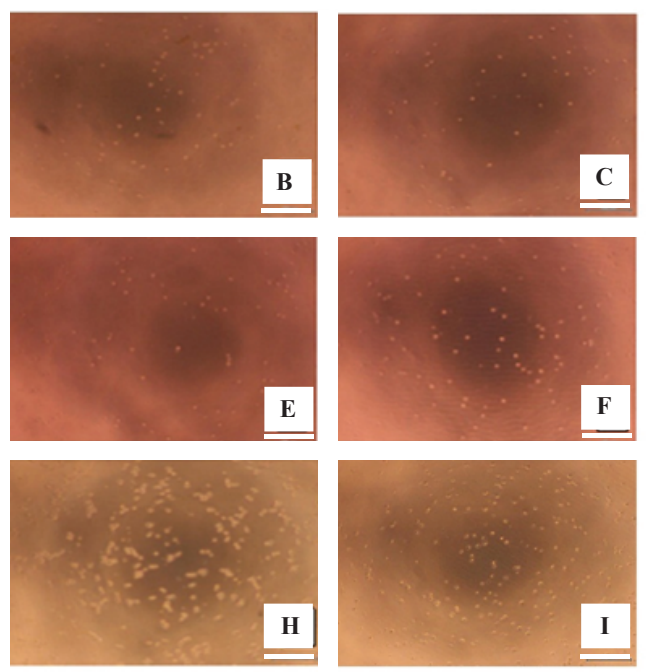

Figure 3. Morphological appearance of HL-60 cells with no treatment (normal cells) and cells with treatment at concentration $100 \mu \mathrm{g} / \mathbf{m L}$. Treatment cells are compound 1 (A), compound 2 (B), compound 3 (C), compound 4 (D), compound 5 (E), compound 6 (F), compound $7(\mathrm{G})$, imatinib $(\mathrm{H})$ and accutan $(\mathrm{I})$. The normal cells relatively has higher density than treated cells. White scale bar: $200 \mu \mathrm{M}$.

7, 4 and 6 exhibited strongest antiproliferative activity respectively among chalcone derivatives tested against T47D (breast cancer cells). The methoxy-4'amino chalcone performed better antiproliferative activity compared to methoxy chalcone derivatives and methoxy-4'-bromo chalcone derivatives. ${ }^{15}$ These results revealed that amino group attached in 4' position played an important role in the growth inhibition of the cancer cells.
It has been postulated that the presence of 4-amino group on first phenyl ring of the chalcones increases their activity and thus their anti-proliferative activity. ${ }^{23,24}{\mathrm{The} \mathrm{IC}_{50}}$ of almost all seven tested compounds were lower in HL-60 cell lines than K562 cell lines, except for Compound 7. K562 is a kind chronic myeloid leukemia that occurs in blastic myeloid transformation which tends to be more aggressive and treatment resistant than other leukemia. ${ }^{25}$ These results
Normal Cells

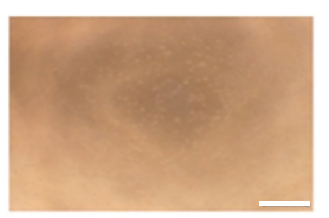

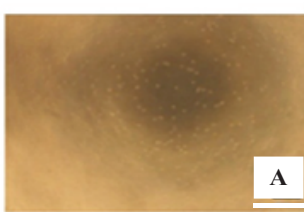
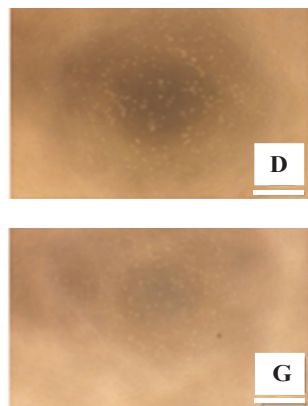

Treated Cells
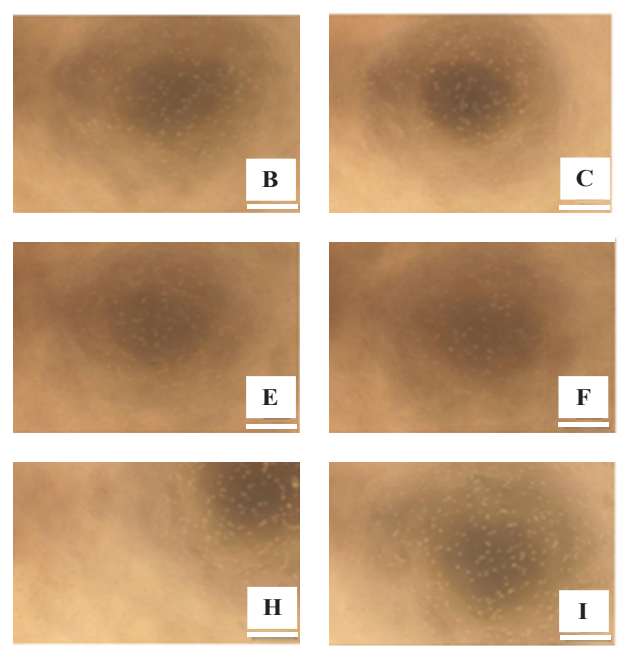

Figure 4. Morphological appearance of lymphocyte cells with no treatment (normal cells) and cells with treatment at concentration $100 \mu \mathrm{g} / \mathbf{m L}$. Treatment cells are compound 1 (1), compound 2 (2), compound 3 (3), compound 4 (4), compound 5 (5), compound 6 (6), compound 7 (7), imatinib (8) and accutan (9). The normal cells relatively has higher density than treated cells. White scale bar: $200 \mu \mathrm{M}$. 
confirmed that HL-60-human acute promyelocytic leukemia cells are more sensitive than K562 cells. ${ }^{26}$

Our study also confirmed that the number and the position of methoxy group play a role in the chalcone derivatives compound anticancer activity. Two coumarincontaining chalcone compounds were compared, compound with a methoxy group at R3 presented increased levels of inhibition. Activity is due to methoxy group in the architecture. ${ }^{27}$ Methoxylated chalcones are structurally similar to combretastatin A-4-5 and colchicine that bind to the tubulin effectively. ${ }^{28,29}$ Several other studies also suggested that the number and the position of methoxy substituents on the aromatic rings appeared to be critical for cytotoxicity. ${ }^{9}$ Generally, all the seven tested compounds had low selectivity toward K562 cells with all SI values below 2 indicate the compounds had general toxicity to cells. ${ }^{19}$ However, Compound 4 showed high selectivity toward HL60 cells, suggesting it have better potential to be use for acute promyelocytic leukemia.

The mechanism of anti-tumor of chalcones remains to be fully clarified. ${ }^{30}$ Some studies reported that chalcone possess the anticancer activity toward HTC116 colon carcinoma cells ${ }^{31}$, leukemia cells (K562 ${ }^{32}$ and HL-60 ${ }^{8}$ ), HepG2 hepato cellular carcinoma cells ${ }^{33}$ prostates cancer $^{34}$ and breast cancer cells (MCF-7 and T47D) ${ }^{35}$. In cancer, chalcones disturbs the signal transduction pathway related to cellular proliferation, angiogenesis, metastasis, apoptosis, and the reversal multidrug resistant. ${ }^{36}$ In this study the structure of chalcones affected the anticancer and cancer selectivity of chalcones derivatives. Study of molecular mechanisms will be pursued in the further research to confirm the anticancer activity of chalcone derivatives compound 1-7 against leukemia cells.

\section{Conclusion}

Dimethoxy group substitution in the position of carbon $2,3,5$ on the second phenyl ring can increase the anticancer activity of 4-amino-chalcones derivatives. The 4-aminochalcone derivatives with methoxy group in the position of carbon 2,3 on the second phenyl ring possess the highest selectivity toward HL-60 leukemia cancer cell lines among all the tested compounds. The results revealed that the number and position of methoxy groups in chalcone derivatives influenced the anticancer and cancer selectivity of chalcone derivatives.

\section{Acknowledgment}

We gratefully acknowledge the financial support from Research Grant 2015-2016 of STIKES Achmad Yani Cimahi, West Java, Indonesia. This research was also supported by Biomedical and Biomolecular Research Centre Aretha Medika Utama, Bandung, West Java, Indonesia for giving facility and laboratory.

\section{References}

1. Campana D, Pui CH. Childhood leukemia. In: Niederhuber JE, Armitage JO, Dorshow JH, Kastan MB, Tepper JE, editors. Abeloff's Clinical Oncology. 4th ed. Philadelphia: Elsevier; 2008. p.2139-69.

2. Modak H, Kulkarni S, Kadakol G, Hiremath S, Patil B, Hallikeri U, et al. Prevalence and risk of leukemia in the multi-ethnic population of North Kartanataka. Asian Pacific J Cancer Prev. 2011; 12: 671-75.

3. Stewart BW, Wild C. World Cancer Report 2014. Lyon: International Agency for Research on Cancer; 2014.

4. Ge H, Kong X, Shi L, Hou L, Liu Z, Li P. Gamma-linolenic acid induces apoptosis and lipid peroxidation in human chronic myelogenous leukemia K562 cells. Cell Biol Int. 2009; 33(3): 402-10.

5. Liang XJ, Chen C, Zhao Y, Wang PC. Circumventing tumor resistance to chemotherapy by nanotechnology. Methods Mol Biol. 2010; 596: 467-88.

6. Nobili S, Lippi D, Witort E, Donnini M, Bausi L, Mini E, et al. Natural compounds for cancer treatment and prevention. Pharmacol Res. 2009; 59(6): 365-78.

7. Millimouno FM, Dong J, Yang L, Li J, Li X. Targeting apoptosis pathways in cancer and perspectives with natural compounds from mother nature. Cancer Prev Res. 2014; 7(11): 1081-107.

8. Saydam G, Aydin H, Sahin F, Kucukoglu O, Erciyas E, Terzioglu E, et al. Cytotoxic and inhibitory effects of 4,4'-dihydroxy chalcone (RVC-588) on proliferation of human leukemic HL-60 cells. Leukemia Res. 2003; 27(1): 57-64.

9. Karthikeyan C, Narayana S, Narayana M, Sakthivel R, Uma V, Elangovan $\mathrm{M}$, et al. Advances in chalcones with anticancer activities. Recent Pat. Anticancer Drug Discov. 2015; 10(1): $97-$ 115.

10. Orlikova B, Tasdemir D, Golais F, Dicato M, Diederich M. Dietary chalcones with chemopreventive and chemotherapeutic potential. Genes. Nutr. 2011; 6(2): 125-47

11. Srinivasan B, Johnson T, Lad R, Xing C. Structure-activity relationship studies of chalcone leading to 3-hydroxy-4,3',4'5'tetramethoxychalcone and its analogues as potent nuclear factor kappa beta inhibitors and their anticancer activities. J Med Chem. 2009; 52(22): 7228-35.

12. Ducki S. Antimitotic chalcones and related compounds as inhibitors tubulin assembly. Anticancer Agents Med Chem. 2009; 9(3): 33647.

13. Mandge S, Singh H, Gupta D, Moorthy H. Synthesis and characterization of some chalcone derivates. Trends Appl Sci Res. 2007; 2(1): 52-6. 
14. Suwito H, Mustofa J, Kristanti A, Puspaningsih N. Chalcones: sythesis, structure diversity and pharmacological aspects. J Chem Pharm Res. 2014; 6(5): 1076-88.

15. Suwito H, Jumina J, Mustofa M, Ni'matuzahroh N, Puspaningsih N. Anticancer and antimicrobial activity of methoxy amino chalcone derivates. Der Pharma Chemica. 2015; 7(3): 89-94.

16. Yoon WJ, Ham YM, Kim SS, Yoo BS, Moon JY. Suppression of proinflammatory cytokines, iNOS and COX-2 expression by brown algae Sargassum micracanthum in RAW 264.7 macrophages. Eur Asia J BioSci. 2009; 3: 130-43.

17. Khan TZ, Wagener JS, Bost T, Martinez J, Accurso FJ, Riches DW. Early pulmonary inflammation in infants with cystic fibrosis. Am. J. Respir. Crit. Care Med. 1995; 151(4): 1075-82.

18. Widowati W, Mosef T, Risdian C, Yellianty Y. Anticancer and free radical scavenging potency of Catharanthus roseus, Dendrophthoe petandra, Piper betle, and Curcuma mangga extract in breast cancer cell lines. Oxid Antioxid Med Sci. 2013; 2(2): 137-42.

19. Badisa RB, Darling-Reed SF, Joseph P, Cooperwood JS, Latinwo LM, Goodman CB. Selective cytotoxic activities of two novel synthetic drugs on human breast carcinoma MCF-7 cells. Anticancer Res. 2009; 29(8): 2993-3006.

20. Chari R. Targeted cancer therapy: confering specificity to cytotoxic drugs. Acc Chem Res. 2008; 41(1): 98-107.

21. Orlikova B, Tasdemir D, Golais F, Dicato M, Diederich M. Dietary chalcones with chemopreventive and chemotherapeutic potential. Genes Nutr. 2011; 6(2): 125-47.

22. Jandial D, Blair C, Zhang S, Krill L, Zhang Y, Zi X. Molecular targeted approaches to cancer therapy and prevention using chalcones. Curr Cancer Drug Targets. 2014; 14(2): 181-200.

23. Dimmock J, Jha A, Zello G, Allen T, Santos C, Balzarini J, et al. Cytotoxic 4'aminochalcones and related compounds. Pharmazie. 2003; 58: 227-32.

24. Vitorovic-Todorovic M, Eric-Nikolic A, Kolundzija B, Hamel E, Ristic S, Juranic I, et al. (E)-4-aryl-4-oxo-2-butaneoic acid amides, chalcone-aroylacrylic acid chimeras: design, antiprolifetarive activity and inhibition of tubulin polymerization. Eur J Med Chem. 2013; 62: 40-50.
25. Maioral M, Gaspar P, Souza G, Mascarello A, Chiaradia L, Licino M, et al. Apoptotic events induced by sythetic naphthylchalcones in human acute leukemia cell lines. Biochimie. 2013; 95(4): 866-74.

26. Brett A, Garry R, Larry W, Burns C. Sensitivity of K562 and HL60 cells to edelfosine, an ether lipid drug, correlates with production of reactive oxygen species. Cancer Res. 1998; 58: 2809-16.

27. Das M, Manna K. Chalcone scaffold in anticancer armamentarium: a molecular insight. J Toxicol. 2016; 2016: 7651047. doi: 10.1155/2016/7651047.

28. Li Q, Li C, Lu X, Zhang H, Zhu H. Design, synthesis and biological evaluation of novel (E)-alpha-benzylsulfonylchalcone derivatives as potential BRAF inhibitors. Eur J Med Chem. 2012; 22(2): 28895.

29. Kong Y, Wang K, Edler M, Hamel E, Mooberry S, Paige M, et al. A boronic acid chalcone analog of combretastatin A-4 as a potent antiproliferation agent. Bloorg Med Chem. 2010; 18(2): 971-77.

30. Ye C, Qian F, Wei D, Lu Y, Liu J. Induction of apoptosis in K562 human leukemia cells by 2',4'-dihydroxy-6'-methoxy-3',5'dimethylchalcone. Leukemia Res. 2005; 29: 887-92.

31. Achanta G, Modzelewska A, Feng L, Khan S, Huang P. A boronic chalcone derivative exhibits potent anti cancer activity through inhibition ofthe proteasome. Mol. Pharm. 2006; 70(1): 426-33.

32. Romagnoli R, Baraldi P, Carrion M, Cara C, Cruz-Lopez O, Preti $\mathrm{D}$, et al. Design synthesis and biological evaluation of tiophene analogues of chalcones. Bioorg Med Chem. 2008; 16(1): 536776.

33. Echeverria C, Santibanez J, Donoso-Tauda O, Escobar C, RamirezTagle R. Structural antitumoral activity relationships of synthetic chalcones. Intl J Mol Sci. 2009; 10(1): 221-31.

34. Szliszka E, Czuba Z, Mazur B, Sedek L, Paradysz A, Krol W. Chalcones enhances TRAIL-induces apoptosis in prostate cancer cells. Int J Mol Sci. 2010; 11(1): 1-13.

35. Ilango K, Valentina $P$, Saluja G. Synthesis and in-vitro anticancer activity of some substitute chalcone derivates. Res J Pharm Biol. Chem. Sci. 2010; 1(2): 354-59.

36. Gutierrez R, Muniz-Ramirez A, Sauceda J. Review: the potential of chalcones as a source of drugs. Afr J Pharm Pharmacol. 2015; 9(8): 237-57. 